\title{
Comparing Experiences of Constitutional Reforms to Enshrine the Right to Water in Brazil, Colombia, and Peru: Opportunities and Limitations
}

\author{
Lara Côrtes $^{1}$, Camila Gianella ${ }^{1,2}\left(\mathbb{D}\right.$, Angela M. Páez ${ }^{3, *(\mathbb{D})}$ and Catalina Vallejo Piedrahíta ${ }^{4,5}$ (D) \\ 1 Centre on Law \& Social Transformation (Law Transform), Chr. Michelsen Institute, N-5892 Bergen, Norway; \\ lara.cortes@cmi.no (L.C.); gianella.c@pucp.edu.pe (C.G.) \\ 2 Department of Psychology, Pontificia Universidad Católica del Perú, Lima 15088, Peru \\ 3 Department of Public Administration, Tennessee State University, Nashville, TN 37203, USA \\ 4 Faculty of Law, Universidad Autónoma Latinoamericana, Medellín 050015, Colombia; \\ catalina.vallejopi@unaula.edu.co \\ 5 Faculty of Law, University of Bergen, N-5020 Bergen, Norway \\ * Correspondence: anicho10@tnstate.edu
}

Citation: Côrtes, L.; Gianella, C.; Páez, A.M.; Vallejo Piedrahíta, C. Comparing Experiences of

Constitutional Reforms to Enshrine the Right to Water in Brazil, Colombia, and Peru: Opportunities and Limitations. Water 2021, 13, 3519 https://doi.org/10.3390/w13243519

Academic Editor: Anas Ghadouani

Received: 18 October 2021

Accepted: 6 December 2021

Published: 9 December 2021

Publisher's Note: MDPI stays neutral with regard to jurisdictional claims in published maps and institutional affiliations.

Copyright: (C) 2021 by the authors Licensee MDPI, Basel, Switzerland. This article is an open access article distributed under the terms and conditions of the Creative Commons Attribution (CC BY) license (https:/ / creativecommons.org/licenses/by/ $4.0 /)$.

\begin{abstract}
In this paper we compare recent efforts towards the constitutionalization of the right to water in Brazil, Colombia, and Peru to understand the opportunities and limitations related to the attempts to enhance access to piped water to the highest normative level. Peru passed a constitutional amendment in 2017 while Brazil and Colombia have seen much right-to-water activism but have not succeeded in passing such reforms. We explore the role of the existing domestic legal frameworks on drinkable water provision and water management towards the approval of constitutional amendments. We find that all three countries have specialized laws, water governing institutions, and constitutional jurisprudence connecting access to water with rights, but the legal opportunity structures to enforce socio-economic rights vary; they are stronger in Colombia and Brazil, and weaker in Peru. We argue that legal opportunity structures build legal environments that influence constitutional reform success. Legal opportunity structures act as incentives both for social movements to push for reforms and for actors with legislative power to accept or reject them. Our findings also show that in some contexts political cost is a key element of constitutional reforms that enshrine the right to water; therefore, this is an element that should be considered when analyzing these processes.
\end{abstract}

Keywords: right to water; constitutional reform; legal opportunity structure; water legal framework; socioeconomic rights; Brazil; Peru; Colombia; social movements; political cost

\section{Introduction}

This paper provides a comparative analysis of constitutional reform attempts in Brazil, Colombia, and Peru for the inclusion of the right to water. There is extensive literature that focuses on constitutional reforms as a mechanism to improve access to water and its impacts, as well as on each country's efforts to protect water rights, but the comparative literature is still underdeveloped. We provide evidence that legal opportunity structures influence constitutional reform success and explain how this occurs in the three case studies. This study is a contribution to scholars and policy makers interested in understanding the regional and domestic dynamics that limit the full implementation of the right to water for all, as urged by the United Nations since 2002 and reinforced in 2010.

Recent efforts towards the constitutionalization of the right to water in Brazil, Colombia, and Peru have led to different results in these countries. While Peru has been successful in enshrining the right to water in the constitution, Brazil and Colombia have seen plenty of right-to-water activism through courts and social protest but have not succeeded in having these reforms approved. In this paper we analyze these constitutional reform processes and explore the role of the existing domestic legal frameworks on drinkable water provision 
and water management towards the approval of such reforms. While recognizing the right to water has different understandings and definitions, this paper focuses on people's access to pipeline water, which has been at the core of the constitutional debates in these countries and the region. We argue that existing legal opportunity structures build legal environments where constitutional reforms are more or less likely to succeed. These legal opportunity structures in turn act as incentives both for social movements to push for reform and for the ones in power (particularly Congresses) to accept or reject it. A key element that has influenced the approval of constitutional reform initiatives by Congresses in these countries is the political cost involved in the decision to constitutionalize the right to water.

In the Latin American region, analyses of the constitutionalization of the right to water in Bolivia and Ecuador have shown the weakness of this right to transform the prevalent neoliberal models of water governance [1-3]. However, each country has its own legal institutions and mechanisms, and what is not transformative in one context might promote important changes in others. There have been attempts to enshrine a right to water in the constitution of several countries, but not all of them have done so. In some countries, the actors involved in these attempts have not been able to mobilize enough political support to pass constitutional reforms. In others, constitutional reforms have faced strong opposition, which could be indicative of a resistance to the potentially transformative effects of water rights. Furthermore, we argue that constitutional reforms in Brazil, Colombia, and Peru have different meanings and roles that are rooted in the existing legal and institutional frameworks for water protection.

The selection of our three countries was based on the following criteria. Firstly, Brazil, Colombia, and Peru are neighboring countries home to more than $80 \%$ of the Amazon rainforest and are among the world's top ten countries in terms of their volume of renewable freshwater resources [4]. Secondly, they face similar challenges in the protection of water resources, such as large-scale resource extraction that is considered central to their economic development strategies. Extractive industries not only challenge the sustainability of water from a human consumption perspective, but they also challenge the livelihood of communities whose culture and identities depend on these water sources. Several regions in these countries are particularly vulnerable to water scarcity, which is often caused or exacerbated by climate change [5-10]. Thirdly, the selected countries are characterized by high inequality, a reason why the water rights of vulnerable groups, such as rural populations, are under threat. It is worth noting that the indigenous populations in these countries are mainly located in rural areas; thus, they are affected by an intersection of marginalization factors [11-14].

Despite these similarities, the outcomes of constitutional reform processes greatly differ from one country to another as do the mechanisms that have been used to advance these reforms. While Peru passed a constitutional reform establishing a freestanding constitutional right to water in 2017, similar efforts in Brazil and Colombia have proven unsuccessful. While in Peru the constitutional reform was led by political parties in Congress, in Brazil and Colombia social movements have also promoted initiatives towards enshrining the right to water but have run into governmental and legislative hurdles that have not been overcome. These different outcomes are puzzling when considering that Peru-relative to the other two countries-has the weakest constitutional protection of economic, social, and cultural rights (ESCR) and that constitutional reforms are much less frequent there.

The 1988 Brazilian constitution and the 1991 Colombian constitution are often referred to as transformative due to their egalitarian aspirations and for the fact that they sought to promote the constitutional protection of social rights [15-19]. At the same time, the constitutional regimes in Brazil (1988), Colombia (1991), and Peru (1993) are part of the phenomenon known as the Latin American neo-constitutional movement which took place in parallel to the expansion of neoliberal reforms [15]. They are not part of the latest wave of Bolivarian socialist regimes which aimed to deeply transform society and regulate the economy [19].

Valuable work has already been completed on an individual country level in exploring the jurisprudence on the right to water, as well as the specific processes surrounding its constitutionalization [2,20-27]. Here we offer a comparative perspective and focus 
particularly on capturing obstacles as well as elements that have fostered constitutional reform processes in the three cases. This paper seeks to contribute to the existing gap in comparative Latin American studies regarding the recognition and protection of the right to water.

We identified relevant norms per country based on whether they regulated access to pipeline water. We included laws, executive decrees, and administrative norms to analyze them based on how they regulated the access to water and stakeholder interests. We also focused on whether these rules created an obligation for the government to protect access to water for the population. Additionally, we build on the assumption that although courts have had different roles in advancing rights protection per country, they can act as catalysts when protecting constitutional and social rights. Moreover, in the case of Brazil and Colombia, the courts have had a salient role in the implementation of the 1988 and 1991 constitutions, respectively [28]. It is worth noting that two of the three countries under analysis are organized as unitary political systems (Perú and Colombia), while Brazil is organized in a federalist political system. For the purpose of this study, we focus on the Brazilian constitution and legislation at the federal level. After identifying relevant regulations per country, we describe key constitutional reform efforts in the access to pipeline water.

Here we focus on domestic legislation that passed starting in the 1990s when neoliberal reforms permeated Latin American countries, particularly in public service provision. Although domestic legislation in the three countries has faced multiple reforms, the foundation for the access to pipeline water was planted in this decade and several of these norms are still in place. Our window of analysis for constitutional reforms starts in 2010 and is based on two criteria: First, we focused on the constitutional reform efforts that gained visibility at the national level in each country, and that allowed us to explore the dynamics between institutional decision-makers.

We acknowledge that there have been important efforts towards the protection of access to pipeline water at the local level, but we have not included them in this study because we are focusing on the interaction between domestic legislation at the national level. Second, we analyze constitutional reform attempts starting in 2010, acknowledging the relevance of the UN General Assembly adopted Resolution 64/292 that recognized access to clean water and sanitation as an independent human right. Finally, our window of analysis ends in 2019. It is our assumption that the world suffered profound changes because of the COVID-19 pandemic with long-lasting effects that are yet to be explored.

The paper is structured as follows: In the first section, we describe the legal status of the right to water in Latin America and provide background on the efforts towards constitutional reforms on the continent. Then we describe the existing legal framework per country in the access to pipeline water, and we identify the relevant institutional actors per country. In the third section, we comparatively analyze the three countries' attempts at constitutional reform and how these reforms interact with existing legal frameworks in each country. Finally, we present our conclusions.

\section{The Legal Status of the Right to Water in Latin America}

When the International Covenant on Economic, Social, and Cultural Rights was adopted in 1966, access to water was not explicitly recognized as a right. In recent decades, however, increased attention has been paid to this right and numerous steps have been taken toward its recognition at the national and international levels.

In 2004, Uruguay was the first country in Latin America to enshrine the right to water in its Constitution, which it did by referendum. Ecuador and Bolivia followed suit in 2008 and 2009, respectively. In all three countries, the constitutional protection of the right to water was introduced largely in response to the wave of privatization of the drinking water supply [2,29]. Behind these reforms lay a claim for equal access to water for all, including those who could not pay the costly tariffs established by private companies. The right thus served as a strategy for resisting the commodification of water and the barriers of many to 
access it. However, only the Uruguayan Constitution forbids the participation of private companies in the distribution and provision of water and sanitation.

The enshrinement of rights into constitutions does not necessarily follow a top-down process whereby international law influences the behavior of nation-states. While constitutional processes must be understood as embedded in broader transnational contexts [30], different countries simultaneously participate in creating international law [31]. Thus, the constitutionalization of the right to water in Uruguay, Ecuador, and Bolivia in the 2000s conversely had effects on the international level. Disputes over the recognition of the right to water in Latin America have been key in shaping its international recognition [1,3].

The steps taken in the international arena to establish a right to water have been driven by a broad coalition of water rights advocates, including civil society representatives and parties seeking to protect private interests around the privatization of water [1,3]. In 2002, the United Nations (UN) Committee on Economic, Social, and Cultural Rights issued General Comment 15, which interpreted the International Covenant on Economic, Social, and Cultural Rights as encompassing a right to water. A comment notes in the Introduction (point 2 ) that this right "entitles everyone to sufficient, safe, acceptable, physically accessible and affordable water for personal and domestic uses." [32].

In 2010, the UN General Assembly adopted Resolution 64/292 recognizing access to clean water and sanitation as an independent human right that is essential for the full enjoyment of life and all human rights. Later that year, the UN Human Rights Council adopted Resolution 15/9, which stated that the right to water and sanitation derives from the right to an adequate standard of living [33]. The normative content for the regulation of the right to water is composed of five criteria also used to regulate other ESCR (as the right to health), i.e., availability, accessibility, quality and safety, affordability, and acceptability [34].

However, as mentioned earlier, the concept of the right to water is still under construction and there is not a consensual interpretation [34]. It is within this context that in 2015, the UN further included access to clean water and improved sanitation among the goals of the 2030 Agenda for Sustainable Development.

Although Brazil, Colombia, and Peru have incorporated international human rights treaties into their constitutions and have ratified the International Covenant on Economic, Social, and Cultural Rights, it is important to keep in mind that this covenant does not explicitly protect the right to water. While General Comment 15 refers to the right to water and the legally binding effects of treaties are broadly accepted, the legal status of general comments, UN resolutions, and development goals are under dispute [35]. However, it is also widely accepted that UN General Assembly resolutions adopted by unanimity are not mere recommendations and can be proof of legally binding international law-be it treatybased or customary [36]. Furthermore, some international law norms are not self-executing, which means that even in cases where treaties have been ratified by a state, an additional incorporation of the treaty rights into domestic constitutions (i.e., a duplication of the rights) increases the probability of their effective enforcement [30].

It is relevant to note that when the aforementioned UN General Assembly resolutions were adopted in 2010, neither Brazil, Colombia, nor Peru had a self-standing right to water in their constitutions. In Colombia, social movements have mobilized around the inclusion of the right to water in the constitution at least since 2007 with no success until now. In 2014, Brazil was recommended to undertake constitutional reform to include the right to water explicitly [37]. Since the changes in international law took place, only Peru among the selected countries has done so.

\section{Materials and Methods}

To explore the dynamics lying behind attempts to introduce constitutional reforms enshrining the right to water we focused on three cases: Brazil, Colombia, and Peru. We analyzed the legal and regulatory framework in each country by identifying the relevant norms that have been in place and that have framed social dynamics in water rights. Our assumption is that these regulations have contributed to the legal environments 
where the constitutional reform movements have been drawing on (either successfully or unsuccessfully). We identified relevant regulations per country based on whether they regulated access to pipeline water. We conducted a content analysis of laws, executive decrees, and administrative regulations focusing on the type of protection they provided to the right to water. In particular, we focused on whether these rules created an obligation for the government to protect water rights to the population. We then related these mechanisms for protection to the content and goals of constitutional reforms per country.

Additionally, we analyzed the jurisprudence of constitutional courts on the access to pipeline water in each country by focusing on how the courts have interpreted the legal framework; we built on the assumption that the role of courts can foster a positive (or negative) environment towards constitutional reforms to protect the right to water. Overall, we analyzed each country's constitution, 12 laws, 5 regulatory rules, 21 constitutional bills, 2 constitutional court rulings, and made a broad analysis of constitutional case law trends based on secondary literature. In Table 1, we summarize the regulations we analyzed.

Table 1. Summary of the materials used.

\begin{tabular}{ccccc}
\hline & Brazil & Colombia & Peru & Total \\
\hline Constitutional court rulings & Analysis of trends & Analysis of trends & 2 & 2 \\
Constitutional bills & $4(2010-2018)$ & $5(2010$ onwards $)$ & $12(2011-2016)$ & 21 \\
Laws & 6 & 2 & 4 & 12 \\
Regulatory rules & 0 & 2 & 3 \\
\hline
\end{tabular}

Source: Prepared by the authors.

\section{Existing National Legal and Regulatory Frameworks}

\subsection{Constitutions}

When the UN resolutions on the human right to water were approved in 2010, Brazil and Colombia already recognized an extensive list of individual as well as economic, social, and cultural rights that could be considered to encompass the right to water. One key feature that distinguishes Brazil and Colombia from Peru is that while the first two countries' constitutions include justiciable social rights, Peru's constitution offers only weak protection for them.

The Peruvian Constitution, in contrast to the Brazilian and the Colombian constitutions, differentiates between fundamental rights-which include the right to life, equality before the law, identity, freedom of conscience and religion, freedom of association and assembly, and free movement, among others-and ESCR, including, inter alia, the right to health, social security, education, and employment. This differentiation provides a strong symbolic message on the status of ESCR in the constitutional design. The Colombian constitution incorporated the same design, and the jurisprudence of its Constitutional Court has linked the satisfaction of certain socio-economic rights to the guarantee of fundamental individual rights (i.e., the social right to health in connection with the fundamental right to life), elevating the first-mentioned category to what is essentially fundamental right status.

The constitutional recognition of ESCR as aspirational rights is a core factor of democratic and social reform in Latin America. As Brinks and Levitsky [38] conclude, aspirational rights can be activated so that gains may be easier to achieve in their presence than in their absence. In the case of Latin America, courts have, by judicial interpretation, activated constitutional aspirational rights.

\subsection{Laws}

By 2010, all three countries had a legal framework for access to pipeline water that responded to the human rights approach embedded in the $2010 \mathrm{UN}$ resolutions. Notably, in the three countries, the models of water governance are in tune with the neoliberal water reforms adopted across Latin America during much of the 1990s, often preceded by Structural Adjustment Policies required by The World Bank, the International Monetary Fund, and the Inter-American Development Bank. 
The implementation of neoliberal water reforms across the region-or the attempts to implement them-in the 1990s were at different levels: resource management, organizational structure, and decision making. They were characterized for promoting a combination of privatization, commercialization, marketization, and re-scaled governance. Reforms sought to put the management of water resources under technical bodies with limited space for political maneuver and community participation [2,39-41].

In each of these countries, water has been recognized as a public good that is exploitable by individuals and private entities through state permits (see Table 2). In 1993, Colombia established human consumption as the main priority for water use (Law 99/1993, art. 1), the Peruvian Law of Water Resources (Law 29338/2009) also prioritizes human consumption over other uses, while in Brazil the 1997 federal law that institutes the national water resources policy states that in situations of scarcity, priority is to be given to human consumption and livestock needs (Law 9.433/1997, art. 1.III).

Table 2. Pre-existing legal framework for the right to water in the selected countries (2010).

\begin{tabular}{|c|c|c|c|}
\hline \multirow{2}{*}{$\begin{array}{c}\text { Some Criterion and } \\
\text { Human Rights Principles }\end{array}$} & \multicolumn{3}{|c|}{ Country } \\
\hline & Brazil & Colombia & Peru \\
\hline Availability & $\begin{array}{c}\text { Law 9.433/1997, art. 1, III, art. 2, I; } \\
\text { Law 11.445/2007, art. 2, I }\end{array}$ & $\begin{array}{l}\text { Constitution, art. } 366 \\
\text { Regime of Public Utilities: } \\
\text { Law 142/1994, art. } 5\end{array}$ & $\begin{array}{l}\text { Law of Water Resources: } \\
\text { Law 29338/2009 } \\
\text { General Sanitation Law: } \\
\text { Law 26338/1994 }\end{array}$ \\
\hline Quality & 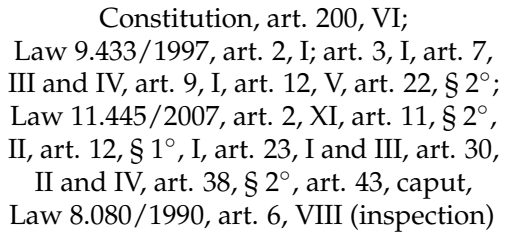 & $\begin{array}{c}\text { Constitution, art. } 367 \\
\text { Regime of Public Utilities: Law } \\
142 / 1994, \text { art. } 68 \\
\text { Decree } 1575 / 2007 \text { and Resolution } \\
\text { 2115/2007 (creating the System for } \\
\text { protection and Control of } \\
\text { Water Quality) }\end{array}$ & $\begin{array}{c}\text { Law of Water Resources: } \\
\text { Law } 29338 / 2009 \\
\text { Law creating the National } \\
\text { Superintendence of Sanitation } \\
\text { Services: Law 25965/1992 }\end{array}$ \\
\hline $\begin{array}{l}\text { Accessibility and } \\
\text { affordability }\end{array}$ & $\begin{array}{l}\text { Law 9.433/1997, art. } 11 \\
\text { Law } 11.445 / 2007 \text {, art. 2, I and II, art. 3, III } \\
\text { and VII, art. } 11, \S 2^{\circ}, \mathrm{IV}, \mathrm{c} \text {, art. } 23 \text {, IX, art. } \\
29, \S 2^{\circ} \text {, art. } 30 \text {, III and VI, art. 31, art. 48, I }\end{array}$ & $\begin{array}{c}\text { Constitution, art. } 368 \\
\text { Regime of Public Utilities: } \\
\text { Law 142/1994, arts. 2, 97, and } 99\end{array}$ & $\begin{array}{l}\text { Law of Water Resources: } \\
\text { Law } 29338 / 2009 \\
\text { Law creating the National } \\
\text { Superintendence of Sanitation } \\
\text { Services: Law } 25965 / 1992\end{array}$ \\
\hline Participation & $\begin{array}{l}\text { River basin committees } \\
\text { (Law } 9.433 / 1997 \text {, arts. 33, III, 37-40) }\end{array}$ & $\begin{array}{c}\text { Water boards: Constitution, art. } 369 \\
\text { Regime of Public Utilities: } \\
\text { Law 142/1994 }\end{array}$ & $\begin{array}{c}\text { Law of Water Resources: } \\
\text { Law 29338/2009 } \\
\text { Organic Law of Municipalities: } \\
\text { Law 27972/2003 }\end{array}$ \\
\hline Operators of water supply & $\begin{array}{l}\text { Municipalities - directly or by } \\
\text { concession or permission } \\
\text { (Constitution, art. 30, V) }\end{array}$ & Private, public, or mixed regimes & $\begin{array}{l}\text { Private, public, or mixed } \\
\text { regimes (Law 25965/1992) }\end{array}$ \\
\hline Ownership of water & $\begin{array}{l}\text { Public good-federal union or } \\
\text { member-states (Constitution, arts. 20, III } \\
\text { and 26, I; Law 9.433/1997, art. 1, I) }\end{array}$ & The Nation & The nation (Constitution art. 66) \\
\hline $\begin{array}{c}\text { Priorities in } \\
\text { water allocation }\end{array}$ & $\begin{array}{l}\text { In case of scarcity, human consumption } \\
\text { and the needs of livestock must be } \\
\text { prioritized (Law } 9.433 / 1997, \text { art. } 1 . \text { III) }\end{array}$ & $\begin{array}{l}\text { Human consumption is prioritized } \\
\text { (Law 99/93, art. } 1 \text { num. 5) }\end{array}$ & $\begin{array}{l}\text { Satisfying human needs is } \\
\text { prioritized (Law of Water } \\
\text { Resources: Law 29338/2009) }\end{array}$ \\
\hline
\end{tabular}

Source: Prepared by the authors.

\subsection{Institutions and Service Providers}

Brazil, Colombia, and Peru have all created national-level bodies tasked with overseeing the quality of water sources and granting water exploitation permits. While in Brazil this body is autonomous and was until 2019 administratively placed under the Ministry of Environment (Law 9.984/2000), water-related functions in Colombia are distributed among various ministries, with the Ministry of Environment as the most important (Law 99/1993).

Meanwhile, in Peru, the water agency is part of the Ministry of Agriculture, which reveals a different institutional approach and tradition regarding water management. In Peru, the management of water sources is still heavily linked to agricultural activities and is almost independent from access to pipeline water, which is linked to state infrastructure. 
More recently the Brazilian agency was administratively placed under the Ministry of Regional Development (Law 13.844, 2019).

In Table 2, we summarize each country's legal framework as of 2010, the year of the UN resolutions, taking into account the human rights criteria and the principles of these resolutions.

A key aspect of the regulatory framework is whether the privatization of pipeline water supply is allowed. Colombia and Peru follow legal models of privatization and have created bodies charged with regulating the supply of water by private companies. These bodies are designed to hold private companies accountable and to guarantee the quality of their services. In Colombia, Law 142 created in 1994 assigned key roles to both the state and the private sector and allowed the creation of public-private partnerships for water provision and management. Peru has a similar law, passed in 1992, that allowed private companies to participate in water provision and management. In Brazil privatization is also possible but has been limited by fragmentation.

Brazil, unlike Colombia and Peru, is a federal republic with three levels of government: local (municipalities), member-state, and federal. The municipalities are responsible for organizing and providing drinking water, whether directly, by concession, or by permission. Although Brazil allows the participation of private actors for water provision, it did not have until 2020 a national regulatory body responsible for basic sanitation services (which includes water supply). This fragmentation between levels of government and the accompanying lack of legal security are seen as major reasons why the participation of private companies in this sector is limited, present in less than $10 \%$ of the municipalities. The Concessions Law enacted in 1995, which regulated the system of concessions and allowed private companies to provide public services (Law 8.987/1995) and the Law on public-private partnerships enacted in 2004 (Law 11.079/2004) have not significantly increased the delivery of water and sanitation services by private enterprises as some believed they would. A recently passed law (Law 14.026/2020) altered the national guidelines for basic sanitation to give the National Water Agency, now the National Water and Basic Sanitation Agency (Agência Nacional de Águas e Saneamento Básico) the power to set standards for basic sanitation services, something that might increase the participation of private companies in the sector. Law 14.026/2020 has passed under extremely particular circumstances due to the Covid-19 pandemic, where the space for debates and lobbing by civil society was limited in comparison to the regular functioning of the congress. Initiatives to revise the national guidelines for basic sanitation in the light of neoliberal reforms had been in place since Michel Temer's term as president (2016-2019) and were strengthened under Bolsonaro's term. Here we highlight that this new law substantially altered the 2007 National Sanitation Law (Law 11.445/2007), which was approved after intense debated in the Congress with the broad participation of several interest groups. Groups opposing the law fear the privatization of the sector, but whether both national and international private actors will invest in basic sanitation in Brazil will depend, among other things, on the legal certainty provided by the law. Several lawsuits have been taken to the Supreme Court to challenge the constitutionality of the Law 14.026/2020.

\subsection{Judicial Protection and Enforcement of Water Rights}

As mentioned above, in the cases under study, the Brazilian and Colombian constitutions are "typical social rights constitutions" [42] while the case of Peru is different. Peru's 1993 Constitution - unlike its predecessor, which had a very comprehensive chapter on social rights-pays scant attention to these rights, whose content is left to the laws.

In Latin America, the jurisprudence on socio-economic rights is closely linked with constitutional design. Constitutional courts play different roles in each country. Among the three cases, the Colombian Constitutional Court is the clearest case of expansive constitutional justice, whereby "the justices themselves [define] influential visions of democratic constitutionalism, defending or expanding the welfare state and extending the benefits of ESCR to previously excluded groups" [42]. As described above, Peru and Colombia share 
some similarities on water regulation that have been framed under a regulatory neoliberal model (such as the creation of independent bodies to supervise the quality of the services supplied by water providers). Given the "constitutional regulatory state" design of the Colombian state under the 1991 Constitution, the Colombian Constitutional Court has a key role in connecting the acts of private providers of public services with the state's obligation to oversee and guarantee the provision of public services [43]. The Colombian Court has intervened to balance, interpret, protect rights, and apply constitutional principles into the neoliberal regulatory scheme for water.

In the case of Brazil, even though it is not possible to state that the intervention of the judiciary has been of the same magnitude as in Colombia when it comes to the right to water, research shows that in cases related to water and sanitation, the courts and the State's Prosecutor Office (Ministério Público) usually intervene to warn public administrators and suppliers about their obligations regarding the rights to water and sanitation [44,45], but there are no rulings by the Supreme Court establishing a right to water.

In Colombia, access to water has been recognized as a human right by the Constitutional Court by way of its connection to the rights to life, health, and a clean environment [27]. Despite this judicial protection, water conflicts remain, particularly in connection to water equality and water sustainability. These challenges are rooted in the lack of a comprehensive government plan to protect the right to water in urban and rural settings. Strong economic activities in the country such as mining and agriculture constantly threaten water sources, while the main political actors struggle under the pressures of lobbying and the awareness of the high costs that the constitutionalization of the right to water would imply (i.e., ensuring a minimum amount of free water supply and reducing the scope of the extractive economy). As it has not been enshrined as a freestanding right in the constitution, the content of the right to water is disputed and the right itself is open to jurisprudential changes.

The interventions of the Colombian Constitutional Court and the legal framework in which it operates have not solved the problem of the lack of access to water in certain communities, but they have proven to be useful tools for the advancement of the protection of the right to access water for certain individuals, and in the context of environmental law cases. This is so, particularly in cases in which low-income petitioners have claimed the right to be reconnected to the water supply despite their inability to pay and have provided evidence of an imminent risk to or violation of their rights to health or life. In this context, the constitutionalization of the right to water would not only have symbolic value but would empower social organizations to demand from the government and the courts a systematic solution to well-known water conflicts, particularly water equality.

Other relevant cases in Colombia have been brought up by rural communities claiming the duty of the state to increase access to water infrastructure (water pipes and sewers) through collective litigation before administrative judges [46]. These cases have generally been decided in favor of vulnerable groups in the application of the collective human right to a healthy environment and public health, but not necessarily of the right to water. The same applies to conflicts involving the protection of rivers and paramos. The courts have decided in favor of an expansive notion of environmental protection including the use of legal categories such as rights of nature and structural judicial decisions. Water as a natural resource and element has thus been key to environmental protection cases in Colombia, and courts have even mentioned the need for the special protection of water sources in the context of climate change. Although it is still too early to tell, the progress achieved in guaranteeing the right to water in Colombia appears to hold the promise, from a transnational law perspective, for further consolidation in the future [27].

In the case of Peru, unlike Brazil and Colombia, the country lacks an institutional opportunity structure that allows easy access to the courts. As with other Latin American countries, Peru has a constitutional writ of protection known as the amparo action. Because of its nature (emergency protection), amparo is one of the least formal constitutional venues: it does not require an evidentiary stage and responds to the principle of flexibility. The 
amparo action allows informal representation, i.e., any person who considers their fundamental rights abused can file a claim for protection in representation of diffuse interests or interest of another person. The Peruvian amparo should in principle provide the same level of protection as Colombia's tutela (also a constitutional writ of protection), but in practice, due to non-formal procedural deadlines that have distorted its urgent purpose, amparo is not an ideal mechanism to seek emergency protection in Peru [47].

On average, an application for amparo and a court order can take more than three months for the judge to decide whether to admit it or not $[48,49]$. So, it can be considered as a feasible route but with limited guarantees for the debate on the content of fundamental rights in the abstract. However, one key feature of the amparo process is its potential impact. Amparo actions can reach the Constitutional Court. When the case is dismissed in second instance, the Constitutional Court can analyze the demand. This means that through an amparo process it is possible to bring the debates to the highest level of constitutional justice.

The main limitation of this is the reluctance of the Peruvian Court to innovate. As mentioned above, Peru has seen less judicial activism on ESCR. Since 2004, the Peruvian Constitutional Court has ruled that such rights are enforceable only to the extent that they conform to the ideals of adequate development of the social purpose of the state, and the enforceability of these rights is restricted to the available budget. In the case of water, the Constitutional Court issued two decisions in 2007 (06534-2006-PA/TC and 6546-2006-PA/TC) recognizing the right to drinking water, linked to fundamental rights, including the rights to life, dignity, and the right to health; however, for the court, the right to water belongs to the group of social welfare rights (derechos prestacionales), which are not part of automatic enforcement (autoaplicables), but depend on the creation of additional legislation and policy. This jurisprudence reflects a key characteristic of the Peruvian Constitutional Court: a formalistic approach that limits the ability of the judiciary to innovate and develop jurisprudence. This feature has been pointed out as a major limitation towards expanding the grounds for rights in general [50] through litigation at the national level.

\section{Discussion: A Comparative View of Constitutional Reforms on the Right to Water in Brazil, Colombia, and Peru}

\subsection{Procedures for Constitutional Reforms per Country}

Article 2016 of the Peruvian Constitution established two mechanisms for amending the Constitution. The first allows Congress to discuss and approve a reform by two-thirds of its members on two consecutive legislatures. Most of the constitutional reforms, including the one to recognize the right to water, have followed this path, and achieving this has required an agreement between different political forces.

The Colombian Constitution can be reformed in three ways: by Congress, by a Constituent Assembly, or by citizens through a referendum (Art 374 Constitution of Colombia). Bills to reform the constitution through Congress can be introduced either by the national government, ten members of the Congress, twenty percent of members of local and regional administrative councils, or by a number of citizens that totals at least five percent of the electoral registry (Art 375 Constitution of Colombia). When following the legislative path, requirements for constitutional reform are stringent since the proposed reform must be discussed in two ordinary session periods, consecutively. In the second period, the reform must be approved by the majority of the members of each Chamber. Constitutional reforms via a constitutional assembly require the approval of both chambers of Congress. Citizens can convene the constitutional assembly if they approve it by at least one-third of the electoral rolls. (Art 376 Constitution of Colombia). The approval of constitutional reforms by means of a referendum requires the approval of Congress via a law approved by the majority of the members of both Chambers prior to the elections. After this approval is granted, elections are held, and they require the total participation of at least one-fourth of the total number of citizens (Art 378 Colombian Constitution). Citizens have attempted constitutional reforms related to the access to pipeline water in the form of referendums, but the Colombian Congress has not been supportive of these initiatives. 
In Brazil, "the Constitution may be amended on the proposal of at least one-third of the members of the Chamber of Deputies or of the Federal Senate; the President of the Republic; or more than one half of the Legislative Assemblies of the units of the Federation, each of them expressing itself by the relative majority of its members" (Article 60 Brazilian Constitution). An amendment proposal is discussed and voted on in two readings in each house of the National Congress (the Chamber of Deputies and the Senate) and will be approved if they obtain 3/5 of the votes of the members of each house in each reading (Article 60 Brazilian Constitution). However, a difficult legislative process in theory has not prevented the constitution from being amended more than a hundred times from 1988 to 2020. In the case of Brazil, the fact that the constitution is highly comprehensive and detail-oriented may have contributed to such an amendment culture.

\subsection{Attempts to Reform the Constitution per Country}

All three countries have seen proposals for constitutionalizing the right to water. In Brazil, four proposals for a constitutional right to water have been presented since 2010, although none progressed to any relevant degree until 2020. Moreover, while most of these proposals refer to the $2010 \mathrm{UN}$ resolution 64/292, the resolution was, surprisingly, not included as a justification for the most recent proposal, which was presented in 2018. It is worth noting that all four proposals refer to a "right to water" without providing a further definition of this right or dealing with the issue of privatization.

Since 2016, a series of measures have been taken in Brazil to strengthen the presence of private actors in the water and sanitation sectors. In July 2018, the president issued a provisional executive order (Medida Provisória 844/2018) to alter the legal framework for sanitation services in the country. The order, expected to stimulate the privatization of the sector and therefore supported by private companies, was not approved by Congress (a necessary step to becoming law). Privatization of water supply services is strongly opposed by a broad coalition of public sector trade unions, environmentalists, left-wing political parties, indigenous groups, academics, and activists in Brazil and abroad. The water crisis in São Paulo in 2014-2016 (city dwellers faced up to 12 hours of water cutoffs daily) is often used as an argument against the privatization of water supply services, which is generally taken as a synonym for the commodification of water. Sabesp, the company that provides water and sewage services in the São Paulo region, is a publicprivate partnership with $49.8 \%$ of its shares trading on the stock exchange. The pressure to secure profits for shareholders is seen by opponents of such partnerships as incompatible with the expansion of services to unprofitable neighborhoods. The tensions around this provisional executive order, and more recently around the above-mentioned newly passed law (Law 14.026/2020), serve to illustrate the difficulties in amending Brazil's Constitution to enshrine the right to water.

In March 2021, the most recent proposal to amend the constitution for the enshrinement of the right to water (PEC 4/2018) was unanimously approved by the Senate. This proposal still has a long way to go before its final approval, but it is intriguing that this unprecedented step was taken less than one year after the approval of a law that is expected to increase the participation of private companies in the water and sanitation services sector.

Meanwhile, Colombia has seen five attempts to reform the Constitution in this direction since 2010 [51], one proposal reached the final voting round in the Senate in 2017 but was defeated (Docket No. 22 March 2017, Senado: 14/2017 Cámara: 282/17). This proposal was presented again for debate in 2020 and is pending. Apart from these reform attempts, there was a major referendum campaign in 2009, which emanated from a network of 150 civil society organizations. The campaign sought a constitutional right to water, a ban on water privatization, state control over water management, the stabilization of tariffs, and a minimum supply of free water for all, which would have a major impact on the disadvantaged that are not able to afford the cost of safe drinking water. The draft referendum bill was dismissed on the basis of being too ambitious and unrealistic; it did not pass Congress [29,52]. 
These reform efforts have created tensions among Colombian political actors, and economic interests have lobbied to stop their materialization. Among the strongest opponents to water rights bills are extractive companies. The establishment of a minimum supply of free water for the most disadvantaged, combined with the strong enforceability of fundamental rights through the tutela mechanism, appears particularly threatening to these economic interests. The government of Colombia has weighed in on these debates, arguing that there would be serious difficulties in the implementation of a right to water, especially in rural areas. The Ministry of Environment has further argued that the government cannot legally commit to developing the necessary infrastructure to bring access to water to rural populations because it would be too costly [51].

The case of Peru is different but not necessarily more promising. Between 2011 and 2012, all political parties presented bills for constitutional amendments in this direction. All these bills originated in Congress-none of them were presented as citizen initiatives. Among the bills, one-issued by a congressperson from Ollanta Humala's ruling partyincluded a provision to ban the participation of private actors in the water supply. During this bill's debate, one actor from outside Congress actively participated: a representative of the SEDAPAL union. SEDAPAL is Peru's largest public water utility. In 2013, all the constitutional amendment proposals were merged into one bill and approved. The new bill did not mention the ban on private companies. The opinion issued by the Constitutional Commission of Congress (where the bills were discussed and approved prior to its submission to the plenary), explicitly stressed the need to recognize the role of private companies in the provision of pipeline water services.

Despite the high level of political confrontation within Congress and between the Congress and the executive branch (which included the censorship of state ministers), Congress asked the executive for an informed opinion (Office of the Prime Minister, Justice, and Human Rights, Ministry of Housing, Construction and Sanitation and the Nation Water Agency-ANA) and received positive feedback. The only agency that issued a negative opinion was the National Superintendence of Sanitation Services-SUNASS, which pointed out that the reform could negatively impact companies supplying water services by denying their right to cut water supply to households with unpaid fees. However, for Congress, this was not a concern. The debates and the opinion issued by the Constitutional Commission of Congress reflect that for legislators, as well as for the executive, the "progressiveness" feature of the right to water is subject to policy processes.

The reform did not trigger demonstrations or massive popular expressions of support or rejection. The constitutional reform was an extraordinary achievement considering the process required (in terms of time and support) and the weakness of the Constitution's provisions on social rights. Unlike Colombia and Brazil, where constitutional reforms are common, since 1993, Peru had passed only six constitutional reforms as of 2018. Since 2018, Peru has gone through a political turmoil, which have involved the resignation of the President Pedro Pablo Kuczynski (March 2018), a referendum to approve constitutional reforms (December 2018), the shutdown of the Congress (September 2019) and the election of a transition Congress 2019-2020 (January 2020). At the core of this political turmoil have been the debate around the constitutional reforms addressing the re-election of the congressmen, political parties financing, political parties' organization, and the immunity of congresspersons.

The fact that Peru passed this constitutional reform whereas Brazil and Colombia have not is puzzling, especially considering that all three countries have supported and accepted international treaties in this sense. It is interesting to observe how the articulation of international and national law varies contextually. Which factors may have influenced this difference? A salient feature of the Peruvian constitutional reform process is that it was supported by a range of political parties. According to some of the representatives directly involved in the process, the political cost of denying the right to water was too high in terms of the reputational costs. Even if the Constitutional reform does not necessarily prevent conflicts, to be portrayed as going against the right to water could have a high political cost 
for stakeholders. Today in Peru, the access, management, and quality of water resources is a trigger for social conflicts [52-54]. The political and reputational costs of supporting the right to water in Peru do not include considerations related to the implementation of this right, which means that Congress did not analyze the costs related in bringing pipeline water to the population. For instance, while the legislators recognized that the right to water could involve investment in infrastructure, this decision was left to the executive. Moreover, neither the legislative nor the executive showed major concerns about the risk of prompting massive litigation which could affect providers as SUNASS did.

In contrast, the 2017 reform attempt in Colombia seemed too costly for congress members to approve because the constitutionalization of access to pipeline water would affect powerful stakeholders such as the government and mining companies. The Colombian government has openly stated its skepticism towards possible constitutional reform to enshrine the right to water due to its financial implications [51]. Particularly, the concerns point to litigation at the Constitutional Court level that is likely to support citizens' lawsuits, especially from rural and peripheral urban areas, with immense costs for the government. At the same time, such possible reform could curtail strong economic interests such as those of the mining industry, with many projects already licensed to transnational corporations and others being strongly lobbied for that purpose. In this case the government and lobbyists use the arguments of economic development to show that the constitutionalization of the right to pipeline water would affect the financial sustainability of the country. Unlike Peru, the analysis of the necessary infrastructure and the fear of litigation via tutelas has dramatically reduced the likelihood of a constitutional reform to be supported in Congress.

As for the case of Brazil, the right to water topic was included in the political agenda for more than one decade, with several proposals to amend the constitution for the enshrinement of this right. However, the legislative processes of these proposals have been minimal, something that suggests that they were strong enough to reach Congress but lacked commitment from congress members to be discussed and voted on. The first time one of these proposals was discussed and voted in the first reading in one of the houses of the National Congress was in March 2021. The strong social mobilization to organize the Alternative World Water Forum in opposition to the World Water Forum in Brazil in 2018 created momentum for the creation of Ondas, the Observatory on the rights to water and sanitation. Water is a cross-cutting topic with great relevance to different groups, Ondas being the most prominent national organization focusing on the right to water. This more cohesive social mobilization, associated with new legislation that is expected to foster privatization in the water supply sector, might influence the next steps of this process of constitutional reform. At the same time, the lack of a further definition of the right to water and the lack of a stand regarding privatization in the proposal in question tend to limit its impact on how Brazilian courts rule on access to water-related issues. In Table 3, we summarize the legal institutional settings for the enforcement of the right to water.

Some actors who have been involved in disputes around the right to water in Peru, while acknowledging the potential positive effects of the constitutional reform, have also highlighted that there is a risk of the right being restricted to household use, ignoring aspects of collective governance over water resources and water flows. In addition, some have voiced concerns regarding the government's capacity to effectively oversee the quality of the water supplied to households and to monitor the quality of water sources more generally. Finally, critics have argued that the government has offered the provision of drinkable water for urban use through water purification systems as a strategy to neglect the complex demands raised by indigenous populations regarding the contamination of water sources in their territories.

In the Colombian case, there are also complex demands from specific populations that have arisen in connection to the access to pipeline water. In the case of indigenous and rural communities, the traditional model of water provision in the country has not been effective. In some cases, rural communities have developed their own community-based aqueducts that follow their own models of management and operate based on the infrastructure 
that these communities have developed [51]. In the case of indigenous communities, access to water is an ongoing issue that the government has failed to address. In these cases, both the cost of bringing the necessary water infrastructure to the regions and the cost involved in articulating existing managerial models, are relevant to the approval of constitutional reforms.

In Peru, as well as in Brazil and Colombia, water quality and availability are affected by increasing deforestation, land grabs, and industrial land uses including mining and extensive agriculture. These problems affect the entirety of society and ecosystems, but affect rural inhabitants, including indigenous peoples, disproportionally.

In the case of Peru, the constitutional reform did little more than enshrine what had already been established through legislation, which was consistent with already existing Constitutional Court jurisprudence. In this sense, the reform was virtually costfree, although it may well prove more difficult to reverse than the previous legal regime. Peru's system for providing potential petitioners with access to justice is comparatively weak, which means that it is unlikely to result in mass litigation by poor individuals and communities. The Peruvian legal framework has already proven insufficient to guarantee access to water for vulnerable populations. The legal framework uses a narrow definition focused on individual urban rights that fail to encompass the collective and cultural aspects of water. This choice of definition has been ineffective at preventing social conflicts around water sources, which are among the main sources of social conflicts in the country [54].

Table 3. Summary of the legal institutional settings for the enforcement of the right to water.

\begin{tabular}{|c|c|c|c|c|}
\hline & Regulations & \multicolumn{2}{|c|}{ Institutional Opportunities for Rights Enforcement } & $\begin{array}{l}\text { Constitutional } \\
\text { Reforms }\end{array}$ \\
\hline & $\begin{array}{l}\text { Privatization of the Drinking } \\
\text { Water Supply }\end{array}$ & $\begin{array}{l}\text { Emergency Protection } \\
\text { through the Courts }\end{array}$ & $\begin{array}{c}\text { Courts Openness } \\
\text { to Innovate, } \\
\text { Expand Rights }\end{array}$ & $\begin{array}{l}\text { Approved } \\
\text { Amendments }\end{array}$ \\
\hline Brazil & Possible & Yes & Strong & None \\
\hline Colombia & Possible & Yes & Very strong & None \\
\hline Peru & Possible & $\begin{array}{l}\text { No (amparo is not so } \\
\text { accessible nor fast) }\end{array}$ & Weak & $\begin{array}{l}\text { One, allowing the } \\
\text { privatization of } \\
\text { drinking water supply. } \\
\text { The constitutional } \\
\text { reform is limited to } \\
\text { drinking water. }\end{array}$ \\
\hline
\end{tabular}

Source: Prepared by the authors.

\section{Conclusions}

As part of the global efforts to extend access to water for all in conditions of quality and equality, during the past decades there has been an interplay of mobilization at the local and international levels to broaden the recognition of a self-standing human right to water. What exactly this right entails is still under construction. In this context, social movements have pushed for legal reform to enshrine this right in the constitutions of Brazil, Colombia, and Peru, with diverse results. These processes are taking place within the mixed context of market liberalization and neo-constitutionalism in Latin America since the 1990s.

All three countries have specialized legal norms and water governing institutions. In the case of Colombia and Peru constitutional jurisprudence has been developed connecting access to water with the rights to life and health, among others. However, the legal opportunity structure to enforce ESCR varies among these countries; it is stronger in Colombia and Brazil, and weaker in Peru. Although water infrastructure and governance have been extended and have become more technical, benefiting large populations especially in urban settings, today in all three cases there is the reality of highly unequal access to water, contamination of water resources stemming from extractive development, and deficiency 
of community participation in water governance. The latter needs might play out in future constitutional reform struggles in Brazil and Colombia.

Protecting ESCR such as the right to water is costly for governments and constitutionalism limits the power of the ruling parties [55]. However, interestingly, not protecting human rights can be politically costly as well. These forces in tension seem to be influencing constitutional reform processes for the enshrinement of water rights in our three case studies.

For some countries, the cost of including a provision within their constitution "may be so low as to effectively render the constitutional promise "cheap talk'," and so "not every country bears a very high cost of adopting constitutional language" [30]. In the case of Peru, there were not high political or economic costs for stakeholders as a consequence of the constitutional reform, while in Colombia the political and financial costs were too high and have discouraged legislators from approving a constitutional reform. Future research will be necessary to assess whether the political costs of constitutional reforms in Colombia will remain high, or whether legal mobilization will change the results of these tensions. In Brazil, it is difficult to say how costly a constitutional amendment to include a right to water would be without further definition of this right, or without dealing with the issue of privatization.

Despite the high political costs of constitutional reforms in Colombia and the unclear situation in Brazil, there are some factors that might motivate relevant actors to keep pushing for changes in the constitutional frames in these countries. For example, as the content of the right to water is disputed and can have both neoliberal as well as collectivist undertones, stakeholders may want to have their preferred interpretation recognized by the constitution. Second, so far jurisprudence has protected the right to water, but jurisprudence is highly dependent on the ideological preferences of magistrates; thus, a constitutional norm that is less open for interpretation can be considered worth mobilizing for.

Our analysis of recent constitutional reform processes in Brazil, Colombia, and Peru leads us to conclude that the enshrinement of the right to water in those constitutions is marked by (i) differences in how diverse interest groups want to use the right to water; (ii) the different incentives guiding members of congress to accept or reject these attempts; and (iii) the existing legal opportunity structures to enforce the right once recognized. These legal opportunity structures in turn act as incentives both for social movements to push for reform and for the ones in power to accept or reject it.

Author Contributions: Conceptualization, L.C., C.G., A.M.P., C.V.P.; methodology, L.C., C.G., A.M.P., C.V.P.; software, L.C., C.G., A.M.P., C.V.P.; validation, L.C., C.G., A.M.P., C.V.P.; formal analysis, L.C., C.G., A.M.P., C.V.P.; investigation, L.C., C.G., A.M.P., C.V.P.; resources, L.C., C.G., A.M.P., C.V.P.; data curation, L.C., C.G., A.M.P., C.V.P.; writing-original draft preparation, L.C., C.G., A.M.P., C.V.P.; writing-review and editing, L.C., C.G., A.M.P., C.V.P.; visualization, L.C., C.G., A.M.P., C.V.P.; supervision, L.C., C.G., A.M.P., C.V.P.; project administration, L.C., C.G., A.M.P., C.V.P.; funding acquisition, L.C., C.G., A.M.P., C.V.P. All authors have read and agreed to the published version of the manuscript.

Funding: This article was prepared with support of the Research Council of Norway-funded project "Elevating water rights to human rights: Has it strengthened marginalized peoples' claim for water?" (Project number 263096).

Institutional Review Board Statement: Interviews for the Colombian case were approved by the Institutional Review Board of Tennessee State University protocol codes \#HS-2018-416 and HS2021-4570, dates of approval 10 September 2018 and 11 April 2021.

Informed Consent Statement: Informed consent was obtained from all subjects involved in the study. 
Data Availability Statement: Two types of data were used for this study. For legislative documents: Publicly available datasets were analyzed in this study. This data can be found here: Brazil: www.planalto.gov.br (accessed on 15 October 2021). Colombia: https:/ / www.Senado.gov. co/index.php/az-legislativo/proyectos-de-ley, http:/ / www.Camara.gov.co/buscador-legislativo (accessed on 24 March 2021). Peru: www.congreso.gob.pe (accessed on 25 January 2019). For interviews: The data are not publicly available due to confidentiality.

Acknowledgments: We want to thank fellow researchers in the project "Elevating water rights to human rights: Has it strengthened marginalized peoples' claim for water?". Their valuable comments and suggestions have enriched and strengthened numerous versions of this manuscript.

Conflicts of Interest: The authors declare no conflict of interest.

\section{References}

1. Clark, C. Of What Use is a Deradicalized Human Right to Water? Hum. Rights Law Rev. 2017, 17, 231-260. [CrossRef]

2. Harris, L.M.; Roa-García, M.C. Recent waves of water governance: Constitutional reform and resistance to neoliberalization in Latin America (1990-2012). Geoforum 2013, 50, 20-30. [CrossRef]

3. Baer, M. From Water Wars to Water Rights: Implementing the Human Right to Water in Bolivia AU. J. Hum. Rights 2015, 14, 353-376. [CrossRef]

4. WorldAtlas. World Facts Which Country Has The Most Fresh Water? 2018. Available online: https://www.worldatlas.com/ articles / countries-with-the-most-freshwater-resources.html (accessed on 15 October 2021).

5. Progressio; CEPES; Water Witness International. Drop by Drop; Progressio: London, UK, 2010.

6. Cirilo, J.A.; Montenegro, S.M.G.L.; Campos, J.N.B. The Issue of Water in the Brazilian Semi-Arid Region, in Waters of Brazil: Strategic Analysis; de Mattos Bicudo, C.E., Galizia Tundisi, J., Cortesão Barnsley Scheuenstuhl, M., Eds.; Springer International Publishing: Cham, Switzerland, 2017; pp. 59-71.

7. Keys, P.W.; Wang-Erlandsson, L.; Gordon, L.J. Revealing Invisible Water: Moisture Recycling as an Ecosystem Service. PLoS ONE 2016, 11, e0151993.

8. Pearce, F. Rivers in the Sky: How Deforestation Is Affecting Global Water Cycles. Yale Environ. 360. Retrieved from 2018. Available online: https: / / e360.yale.edu/features/how-deforestation-affecting-global-water-cycles-climate-change (accessed on 15 October 2021).

9. IPCC. AR5 Climate Change 2014. Impacts, Adaptation, and Vulnerability: 27 Central and South America; 2014; Available online: https:/ / www.ipcc.ch/report/ar5/wg2/ (accessed on 15 October 2021).

10. Marzano, K. Tackling Climate Change in Latin America; Konrad Adenauer Foundation, Regional Programme Energy Security and Climate Change in Latin America: 2016; Available online: https:/ /www.kas.de/c/document_library/get_file?uuid=ba43934b-d004 $\backslash$ protect \unhbox \voidb@x \hbox\{-4ca5\}-4519-58ce8a3dbd98\&groupId=252038 (accessed on 5 December 2021).

11. World Health Organization and UNICEF. Joint Monitoring Programme for Water Supply, Sanitation and Hygiene (JMP). 2018. Available online: https: / / washdata.org/ (accessed on 23 January 2019).

12. World Health Organization; United Nations Children's Fund. Progress on Drinking Water, Sanitation and Hygiene: 2017 Update and SDG Baselines; World Health Organization (WHO) and the United Nations Children's Fund (UNICEF): Geneva, Switzerland, 2017.

13. Miranda, M.; Aramburú, A.; Junco, J.; Campos, M. Situación de la calidad de agua para consumo en hogares de niños menores de cinco años en Perú, 2007-2010. Rev. Peru. Med. Exp. Salud Publica 2010, 27, 506-511. [CrossRef] [PubMed]

14. The World Bank. Water and Sanitation Services:Achieving Sustainable Outcomes with Indigenous Peoples In Latin America and the Caribbean; The World Bank: Washington, DC, USA, 2016.

15. Roa-García, M.C.; Urteaga-Crovetto, P.; Bustamante-Zenteno, R. Water laws in the Andes: A promising precedent for challenging neoliberalism. Geoforum 2015, 64, 270-280. [CrossRef]

16. Baxi, U. Preliminary Notes on Transformative Constitutionalism. In Proceedings of the BISA Conference: Courting Justice, New Delhi, India, 27-29 April 2008.

17. Countinho, D.R. Linking promises to policies: Law and development in an unequal Brazil. Law Dev. Rev. 2010, 3, 3-40.

18. Vieira, O.V. Supremocracia. Rev. Direito GV 2008, 4, 441-464. [CrossRef]

19. Brinks, D.M. The transformation of the Latin American State-As-Law: State Capacity and the Rule of Law. Rev. Cienc. Politica 2012, 32, 561-583. [CrossRef]

20. Ku Yanasupo, L. El derecho al agua y el debate sobre su posible constitucionalización. Gac. Const. Procesal Const. 2014, 75, 51-58.

21. Santos, C.; Villareal, A. Uruguay: Direct Democracy in Defense of the Right to Water; The Transnational Institute: Amsterdam, The Netherlands, 2006.

22. Water Lex; WASH United. The Human Rights to Water and Sanitation in Courts Worldwide; Water Lex: Geneva, Switzerland, 2014.

23. Achkar, M.; Dominguez, A.; Pesce, F. La defensa del agua como recurso público en Uruguay: El caso de la comisión nacional en defensa del agua y la vida y el plebiscito por el agua. ORG DEMO 2005, 6, 37-50. [CrossRef]

24. Boelens, R. The Politics of Disciplining Water Rights. Dev. Chang. 2009, 40, 307-331. [CrossRef]

25. Haglund, L. Can Human Rights Challenge Neoliberal Logics? Evidence from Water and Sanitation Rulings in São Paulo, Brazil. In Economic and Social Rights in a Neoliberal World; MacNaughton, G., Frey, D.F., Eds.; Cambridge University Press: Cambridge, UK, 2018; pp. 323-337. 
26. Díaz-Pulido, A.-P.; Hernández, N.C.; Muñoz-Moreno, D.; Olaya-González, W.R.; Perilla-Castro, C.; Sánchez-Ojeda, F.; Sánchez-González, K. Desarrollo sostenible y el agua como derecho en Colombia. Rev. Estud. Socio Jurídicos 2009, 11, 84-116.

27. Giupponi, M.B.; Paz, M.C. The Implementation of the Human Right to Water in Argentina and Colombia. Anu. Mex. Derecho Int. 2015, 15, 323-352. [CrossRef]

28. Vieira, O.V. Ambitious constitutions: Prominent courts. In Comparative Constitutional Law in Latin America; Dixon, R., Ginsburg, T., Eds.; Edward Elgar Publishing: Cheltenham, UK; Northampton, MA, USA, 2017.

29. Langford, M.; Rodriguez, -G.C.; Rossi, J. Compliance with Socio-Economic Rights Judgments. Making It Stick; Cambridge University Press: Cambridge, UK, 2017.

30. Elkins, Z.; Ginsburg, T.; Simmons, B.A. Getting to rights: Treaty ratification, constitutional convergence, and human rights practice. Harv. Int. Law J. 2013, 54, 61-95.

31. Waltz, S. Reclaiming and Rebuilding the History of the Universal Declaration of Human Rights. Third World Q. 2002, 23, 437-448. [CrossRef]

32. Economic, UN; Social Council. General Comment No. 15 (2002) The right to water (arts. 11 and 12 of the International Covenant on Economic, Social and Cultural Rights). Agenda 2002, 11, 29.

33. UN Human Rights Council. 15/9 Human Rights and Access to Safe Drinking Water and Sanitation; GE.A/HRC/15/31/Add.1. 0-16633; 2010; Available online: https:/ / www.right-docs.org/doc/a-hrc-res-15-9/ (accessed on 5 December 2021).

34. Brown, C.; Neves-Silva, P.; Heller, L. The human right to water and sanitation: A new perspective for public policies. Ciência Saúde Coletiva 2016, 21, 661-670. [CrossRef]

35. Schutter, O.D. International Human Rights Law: Cases, Materials, Commentary; Cambridge University Press: Cambridge, UK, 2014.

36. Gaviria Liévano, E. Derecho Internacional Público; Editorial Temis: Bogotá, Colombia, 2006.

37. UN Special Rapporteur on the Human Right to Safe Drinking Water and Sanitation. Report of the Special Rapporteur on the Human Right to Safe Drinking Water and Sanitation, Catarina de Albuquerque, Mission to Brazil (9 to 19 December 2013); 2014; Available online: https:/ / digitallibrary.un.org/record/777974?ln=zh_CN (accessed on 15 October 2021).

38. Brinks, D.M.; Levitsky, S.; Murillo, M.V. Understanding Institutional Weakness: Power and Design in Latin American Institutions; Cambridge University Press: Cambridge, UK, 2019.

39. Marston, A.J. Autonomy in a post-neoliberal era: Community water governance in Cochabamba, Bolivia. Geoforum 2015, 64, 246-256. [CrossRef]

40. Perera, V. Engaged Universals and Community Economies: The (Human) Right to Water in Colombia. Antipode 2015, 47, 197-215. [CrossRef]

41. Heller, L. Water and Sanitation Policies in Brazil: Historical Inequalities and Institutional Change. In Water and Sanitation Services. Public Policy and Management; Castro, J.E., Heller, L., Eds.; Routledge: London, UK, 2009; pp. 321-337.

42. Brinks, D.M.; Blass, A. The DNA of Constitutional Justice in Latin America. Politics, Governance and Judicial Designs; Cambridge University Press: Cambridge, UK; New York, NY, USA; Port Melbourne, Australia; New Delhi, India; Singapore, 2018.

43. Urueña, R. The rise of the constitutional regulatory state in Colombia: The case of water governance. Regul. Gov. 2012, 6, 282-299. [CrossRef]

44. Haglund, L. Water governance and social justice in São Paulo, Brazil. Water Policy 2014, 16 (Suppl. 2), 78-96. [CrossRef]

45. Barcellos, A.P. Sanitation Rights, Public Law Litigation, and Inequality: A Case Study from Brazil. Health Hum. Rights 2014, 16.

46. Páez-Murcia, Á.M.; Lamprea-Montealegre, E.; Vallejo-Piedrahita, C. Medio ambiente y acciones populares en Colombia: Un estudio empírico. Vniversitas 2017, 66, 209-248. [CrossRef]

47. Ramírez Huaroto, B.; Álvarez, B. Derecho y aborto. Forseti. Rev. Derecho 2016, 6, 76-96. [CrossRef]

48. Abad Yupanqui, S. La sentencia estimatoria de amparo: La difícil ruta para su ejecución. Ius Veritas 2014, 48, $244-255$.

49. Defensoría del Pueblo. Informe $N^{\circ} N^{\circ}$ 172. Estudio del Proceso de Amparo en el Distrito Judicial de Lima: Fortaleciendo la Justicia Constitucional; Defensoría del Pueblo: Lima, Peru, 2015.

50. Gianella, C.; Alvarez, B. Judicial Lawfare: Analysis of legal arguments against abortion rights in Peruvian courts. Forthcoming.

51. Páez, A.M.; Piedrahíta, C.V. Channeling Water Conflicts through the Legislative Branch in Colombia. Water 2021, $13,1214$. [CrossRef]

52. Defensoría del Pueblo. Reporte de Conflictos Sociales No 166; Defensoría del Pueblo: Lima, Peru, 2017.

53. Defensoría del Pueblo. Reporte de Conflictos Sociales No. 178; Defensoría del Pueblo: Lima, Peru, 2018.

54. Defensoría del Pueblo. Conflictos Sociales y Recursos Hídricos. Serie Informes de Adjuntía-Informe N 001-2015-DP/APCSG; Defensoría del Pueblo: Lima, Peru, 2015.

55. Farber, D.A. Rights as Signals. J. Leg. Stud. 2002, 31, 83-98. [CrossRef] 